\title{
The production and characterization of anti-bovine CD14 monoclonal antibodies
}

\author{
Eun J. SOHN ${ }^{\mathrm{a}}$, Max J. PAAPE ${ }^{\mathrm{b} *}$, Robert R. PETERS ${ }^{\mathrm{a}}$, \\ Raymond H. FETTERER ${ }^{\mathrm{c}}$, Neil C. TALBOT ${ }^{\mathrm{d}}$, Douglas D. BANNERMAN ${ }^{\mathrm{b}}$ \\ ${ }^{a}$ Department of Animal and Avian Sciences, University of Maryland, College Park, MD 20742, USA \\ ${ }^{b}$ Bovine Functional Genomics Laboratory, USDA-ARS, Beltsville, MD 20705, USA \\ ${ }^{c}$ Animal Parasitic Diseases Laboratory, USDA-ARS, Beltsville, MD 20705, USA \\ d Biotechnology and Germplasm Laboratory, USDA-ARS, Beltsville, MD 20705, USA
}

(Received 12 January 2004; accepted 13 April 2004)

\begin{abstract}
To characterize further the chemical and biological properties of bovine soluble (bos) $\mathrm{CD} 14$, a panel of ten murine monoclonal antibodies $(\mathrm{mAb})$ reactive with recombinant $(\mathrm{r})$ bosCD14 were produced. A sandwich ELISA, using murine $\mathrm{mAb}$ and rabbit polyclonal antibodies reactive with rbosCD14 was developed. All the mAb were reactive by ELISA with baculovirus-derived rbosCD14 and they recognized rbosCD14 $(40 \mathrm{kDa})$ by western blot analysis. The mAb also identified by western blot sCD14 (53 and $58 \mathrm{kDa})$ in milk and blood and SCD14 (47 kDa) in a lysate of macrophages obtained from involuted bovine mammary gland secretions. Analysis by ELISA of whey samples after intramammary injection of lipopolysaccharide (LPS) $(10 \mu \mathrm{g})$ revealed increased sCD14 levels between 8 to $48 \mathrm{~h}$ after injection. Flow cytometric analysis showed that the mAb bound to macrophages isolated from involuted mammary gland secretions and mouse macrophages but not to swine or horse monocytes. Addition of anti-rbosCD14 mAb to monocytes stimulated with LPS reduced in vitro production of TNF- $\alpha$. The anti-rbosCD14 antibodies generated in this study will be useful in studying CD14, an accessory molecule that contributes to host innate recognition of bacterial cell wall components in mammary secretions produced during mastitis.
\end{abstract}

CD14 / monoclonal antibodies / ELISA / LPS / mastitis

\section{INTRODUCTION}

CD14 was first described as a monocyte/ macrophage differentiation antigen that is attached to the cell surface by a glycosylphosphatidylinositol (GPI) anchor [17]. Membrane CD14 (mCD14) is a $55 \mathrm{kDa}$ glycoprotein which binds lipopolysaccharide (LPS) and initiates cell activation. This receptor is abundant on the cell membrane of mono- cytes and macrophages and is present at a lower density on polymorphonuclear neutrophil leukocytes (PMN) [1]. Soluble CD14 (sCD14) has been detected in bovine milk [23], and in human serum and urine [4, 17, 26]. Membrane CD14 is an accessory receptor for LPS that activates monocytes, and is capable of binding low concentrations of LPS that are complexed to serum-derived LPS-binding protein (LBP) [39].

\footnotetext{
* Corresponding author: mpaape@anri.barc.usda.gov
} 
Soluble CD14 exists in at least two isoforms which range in size from $48-56 \mathrm{kDa}$ [8]. Soluble CD14 found in human serum has been attributed to the shedding of mCD14 from monocytes, macrophages and PMN $[8,20]$ Studies with human monocytes and monocytic cell lines have shown that $\mathrm{mCD} 14$ is released via protease-dependent or independent pathways. Some isoforms originate from shedding of mCD14, while others are secreted after synthesis by monocytes and macrophages [5]. Soluble CD14 present in the serum/plasma and urine of nephritic patients mediates activation of cells not bearing mCD14 including epithelial cells and endothelial cells $[2,15]$. Macrophages are the predominant cell type in milk from uninfected bovine mammary glands whereas PMN predominate in mastitic milk. Bovine macrophages and PMN in milk express mCD14 on their cell surface [28] and are potential sources of sCD14.

Recognition of LPS involves soluble proteins, membrane receptors (CD14 and Tolllike receptor 4) and intracellular signaling amplification machinery. LBP promotes rapid binding of LPS and forms aggregates that bind to mCD14 [39]. Membrane CD14 is important for conferring sensitive cellular responses to LPS. LPS induction of cytokine release, particularly TNF- $\alpha$ and IL- 1 , is probably the central most important event in initiating the acute-phase response to infection [3]. LPS stimulates the cells by ligating specific membrane receptors like CD14 that are important for cytokine release. Anti-CD14 mAb blocks release of TNF- $\alpha$ from macrophages $[6,18,39]$ and protects primates from endotoxin shock $[9,35]$.

Bovine coliform mastitis is an inflammation of the mammary gland caused by Gram- negative bacteria, where Escherichia coli is the most common pathogen [10,19]. About $40-50 \%$ of all clinical cases of mastitis are caused by coliform bacteria [27]. Mastitis results in decreased milk production, increased veterinary costs, and culling and death of animals. Coliform mastitis is the most prevalent form of clinical mastitis, with infection by Escherichia coli being the most frequent. Approximately $80 \%$ of all intramammary infections by coliform bacteria will result in clinical mastitis, and about $25 \%$ of the cows will develop acute clinical symptoms [11, 12]. Coliforms are present in the cow's environment and they cannot be eradicated on a practical basis. Conventional herd management practices such as pre- and post-milking teat dipping, and dry cow antibiotic therapy have been unable to reduce the incidence of new intramammary infections by coliforms. Even in wellmanaged herds coliform mastitis continues to exist as an animal health problem. In addition, antibiotic treatment, extensive fluid supplementation and metabolic support are not effective in relieving symptoms associated with clinical coliform mastitis [27]. Anti-bovine CD14 mAb may provide a means of reducing clinical symptoms during acute coliform mastitis by blocking the binding of LPS to mCD14 on monocytes and macrophages, thus down-regulating release of inflammatory mediators like TNF- $\alpha$ and IL-1. The objectives of this study were to: (1) produce anti-rbosCD14 mAb that could be used to reduce release of inflammatory cytokines from bovine macrophages, and (2) develop an ELISA for quantitating bovine sCD14.

\section{MATERIALS AND METHODS}

\subsection{Production of rbosCD14}

The rbosCD14 was produced in a baculovirus expression system as previously described [38]. Briefly, rbosCD14, with a deletion of 14 amino acids at the C-terminal end, was generated by insect sf/9 cells infected with recombinant virus containing the gene. The rbosCD14 was purified from culture supernatant using Ni-NTA superflow agarose beads (Qiagen, Valencia, CA, USA) and FPLC system (Amersham Pharmacia, Uppsala, Sweden) with a typical yield of $4-6 \mathrm{mg} / \mathrm{L}$ of culture supernatant. Functional analysis of the rbosCD14 showed 
that it reduced mortality in mice from endotoxin shock and reduced severity of intramammary infection in mice and cows after experimental challenge with E. coli [24, 25].

\subsection{Hybridoma production and $\mathbf{m A b}$ purification}

Four female BALB/c mice (National Cancer Center, Fredrick, MD, USA) were immunized intraperitoneally biweekly with $50 \mu \mathrm{g}$ of rbosCD14 emulsified in Freund's adjuvant (Sigma, St. Louis, MO, USA). Six weeks after the second injection and three days prior to fusion, mice were boosted by intravenous injection of $25 \mu \mathrm{g}$ of rbosCD14 in $0.5 \mathrm{~mL}$ of $0.01 \mathrm{M}$ phosphate buffered $0.85 \%$ saline, $\mathrm{pH} 7.4$ (PBS). Mice producing high serum antibody titers to rbosCD14 were selected by ELISA, and their spleen lymphocytes were fused with mouse myeloma SP 2/0 cells (ATCC, Rockville, MD, USA). Hybridomas were selected in medium supplemented with hypoxanthine, aminopterin, and thymidine (Sigma), and supernatants screened by ELISA (see below). Hybridomas secreting rbosCD14 antibodies were cloned by limiting dilution using mouse thymus feeder cells. Ascites were produced in female $\mathrm{BALB} / \mathrm{c}$ mice following intraperitoneal injection with $0.5 \mathrm{~mL}$ of $2,6,14$, 20-tetramethypentadecane (Sigma). Use of animals for this investigation was approved by the Beltsville Agricultural Research Center's Animal Care and Use Committee.

\subsection{Polyclonal antibody production}

The immunization protocol is described in detail by Fretterer and Barfield [13]. Briefly, a New Zealand white female rabbit, 4-5 pounds and specific pathogen-free, was purchased from Covance Research Products (Denver, PA, USA). The ImmuMax SR adjuvant system, an immunostimulatory biomolecule, surfactant and oil (Zonagen Inc., The Woodlands, TX, USA), was used to form an emulsion containing $15 \mu \mathrm{g}$ of rbosCD14. The mixture of gel, rbosCD14 and ImmuMax SR chitosan was brought to pH 7.0 and emulsified with the surfactant and oil immediately before being injected subcutaneously into the scapular arch of the rabbit. Total volume of the injection was $1.0 \mathrm{~mL}$ and was spread over 3-4 injection sites. On day 30 post-immunization, this procedure was repeated. Before immunization, rabbits were bled from the central auricular artery to obtain baseline control sera. At 37 days post-immunization, a second blood sample was obtained to determine positive antibody response and titer.

\subsection{Isotyping of $\mathrm{mAb}$}

A mouse hybridoma isotyping ELISA kit (Biomeda, Foster City, CA, USA) was used to isotype the mAb. Using 96-well microtiter plates, $50 \mu \mathrm{L}$ of antigen solution was added to each well and incubated for $3 \mathrm{~h}$ at $37^{\circ} \mathrm{C}$. The plates were washed once with PBS, followed by addition of $200 \mu \mathrm{L}$ of $1 \%$ bovine serum albumin (BSA) blocking solution to each well and incubated for $1 \mathrm{~h}$ at $37^{\circ} \mathrm{C}$. Hybridoma supernatant $(100 \mu \mathrm{L})$ was added to each well and $50 \mu \mathrm{L}$ of classand subclass specific anti-mouse antibodies was added to the plates and incubated for $30 \mathrm{~min}$ at $37^{\circ} \mathrm{C}$. After washing the plates $3 \times$ with PBS, $50 \mu \mathrm{L}$ of rabbit anti-goat IgG conjugated to horseradish peroxidase (BioRad) was added to each well and incubated for $30 \mathrm{~min}$ at $37^{\circ} \mathrm{C}$. After washing the plate $3 \times$ with PBS, $100 \mu \mathrm{L}$ of 3, 3', 5, 5'-tetramethylbenzidine (TMB) chromogen/substrate solution (Sigma) was added to each well. The reaction was stopped by adding $50 \mu \mathrm{L}$ of $2 \mathrm{~N}$ sulfuric acid, yielding a yellow color. Absorbance was measured using a microtiter plate reader (Bio-Tek Instruments Inc., Winooski, VT, USA) at a wavelength of $450 \mathrm{~nm}$.

\subsection{Screening for production of anti-rbosCD14}

Flat bottom 96-well microtiter plates (Dynex Technologies Inc., Chantilly, VA, USA) were coated with $100 \mu \mathrm{L}$ of rbosCD14 
Table I. Immunoglobulin isotype and results from ELISA and western blot analysis for the ten $\mathrm{mAb}$ developed in this study.

\begin{tabular}{lccccc}
\hline Mab & Isotype & \multicolumn{2}{c}{ ELISA } & \multicolumn{2}{c}{ Western blot } \\
\cline { 2 - 6 } & & bosCD14 & Control & bosCD14 & Control \\
\hline M1-54-1 & IgG1,K & +++ & - & +++ & - \\
M1-34-2 & IgG2b,K & +++ & - & ++ & - \\
M1-6-6 & IgG2b,K & +++ & - & +++ & - \\
M3-3-8 & IgM,K & +++ & - & + & - \\
M1-34-9 & IgG2b,K & +++ & - & ++ & - \\
M2-7-7 & IgG3,K & +++ & - & +++ & - \\
M1-54-2 & IgG1,K & +++ & - & +++ & - \\
M4-2-3 & IgM,K & +++ & - & +++ & - \\
M5-29-3 & IgM,K & +++ & - & +++ & - \\
M5-2-8 & IgM,K & +++ & - & + & - \\
\hline
\end{tabular}

+: weak reactivity, ++: moderate reactivity, +++ : strong reactivity.

$(10 \mu \mathrm{g} / \mathrm{mL}$ in $0.1 \mathrm{M}$ carbonated-bicarbonate buffer $\mathrm{pH}$ 9.6) and incubated at $4{ }^{\circ} \mathrm{C}$ for $16 \mathrm{~h}$. The plates were washed $3 \times$ with PBS containing $0.05 \%$ (v/v) Tween 20 (PBS-T). Each well was blocked with $200 \mu \mathrm{L}$ of PBS containing $1 \%(\mathrm{w} / \mathrm{v}) \mathrm{BSA}$ (Sigma) for $1 \mathrm{~h}$ at room temperature and washed $3 \times$ with PBS-T. Hybridoma supernatants $(100 \mu \mathrm{L})$ were added and incubated for one hour at room temperature, and washed $3 \times$ with PBS-T. One-hundred microlitres of HRP-conjugated goat anti-mouse IgG (H+L; Sigma) diluted 1:2000 in PBS-0.1\% BSA was added, and plates incubated for $1 \mathrm{~h}$ at room temperature. The plates were washed $3 \times$ with PBS and then $100 \mu \mathrm{L}$ of $0.01 \%(\mathrm{w} / \mathrm{v})$ TMB in $0.05 \mathrm{M}$ phosphate - citrate buffer, $\mathrm{pH} 5.0$ was added and incubated at room temperature for $15 \mathrm{~min}$. The reaction was stopped with $50 \mu \mathrm{L}$ of $2 \mathrm{~N}$ sulfuric acid. Color change was measured by an automated microtiter plate reader (Bio-Tek Instruments) at a wavelength of $405 \mathrm{~nm}$.

\subsection{Preparation of milk whey and blood plasma}

Milk was obtained from five cows at intervals over a $72 \mathrm{~h}$ period after intramammary injection of $10 \mu \mathrm{g}$ of lipopolysaccharide (LPS, E. coli 0111:B4, Sigma) LPS $(10 \mu \mathrm{g})$ dissolved in $10 \mathrm{~mL}$ of $0.85 \%$ saline and sterile filtered through a $0.22 \mu \mathrm{m}$ cellulose acetate filter (Corning Incorporated, Corning, NY, USA). The right or left front mammary quarters were infused with either $10 \mathrm{~mL}$ of saline alone or LPS.

For the preparation of whey, milk samples were centrifuged at $44000 \times g$ at $4{ }^{\circ} \mathrm{C}$ for $30 \mathrm{~min}$, and the fat layer was removed with a spatula. The skimmed milk was centrifuged again for $30 \mathrm{~min}$ as above, and the translucent supernatant collected and stored at $-70^{\circ} \mathrm{C}$ in aliquotes. Blood samples were obtained from the tail vein and collected in glass tubes containing $\mathrm{K}_{2}$ EDTA (BectonDickinson Corp, Franklin Lakes, NJ, USA), centrifuged at $1500 \times g$ for $15 \mathrm{~min}$, and the clear plasma supernatant was collected and stored at $-70^{\circ} \mathrm{C}$ in aliquotes.

\subsection{Sandwich ELISA for SCD14 in cow milk after challenge with LPS}

A sandwich ELISA was used to quantify sCD14 levels in milk whey. Flat-bottom 96-well plates were coated with $5 \mu \mathrm{g} / \mathrm{mL}$ of mouse anti-rbos CD14 mAb M1-54-2 diluted in $0.05 \mathrm{M}$ sodium carbonate, $\mathrm{pH} 9.6$ at $4{ }^{\circ} \mathrm{C}$. This mAb was selected because it gave an intensely stained band when used in the western blot (Tab. I). The plates were washed $4 \times$ with $0.05 \%$ Tween 20 diluted 
in $50 \mathrm{mM}$ Tris buffered saline (TBS), $\mathrm{pH}$ 8.0 , and subsequently blocked with $2 \%$ fish skin gelatin (Sigma) for $1 \mathrm{~h}$ at room temperature. Plates were washed and $100 \mu \mathrm{L}$ of undiluted whey samples were added to each well. Rabbit anti-bovine CD14 polyclonal antibody was diluted 1:2000 in TBS buffer containing $0.2 \%$ gelatin, and $100 \mu \mathrm{L}$ was added to each well and subsequently washed as above. One-hundred microlitres of HRPconjugated goat anti-rabbit $\operatorname{IgG}(\mathrm{H}+\mathrm{L}$; Promega) diluted in PBS containing 0.2\% gelatin (1:5000) was added to each well. Plates were incubated for $1 \mathrm{~h}$ at room temperature, washed as above, and $100 \mu \mathrm{L}$ of TMB substrate solution added to each well. The reaction was stopped by the addition of $50 \mu \mathrm{L}$ of $2 \mathrm{~N} \mathrm{H}_{2} \mathrm{SO}_{4}$ and the absorbance read at $450 \mathrm{~nm}$ on a microplate reader (Bio-Tek Instruments, Inc.). Concentrations of sCD14 were calculated by reference to a standard curve obtained by incorporating a series of concentrations of rbosCD14 in the assay.

\subsection{Isolation of macrophages and monocytes and cultivation in vitro}

Bovine mammary gland macrophages were obtained by daily infusion of $50 \mathrm{~mL}$ of sterile isotonic saline solution into the involuted mammary quarter of three normal adult cows for five consecutive days [7]. To avoid infection of the gland, the teat orifice was washed with $70 \%$ ethanol, and a sterile teat cannula was used to infuse the saline. Following gentle massage, the suspension was milked out into a $50 \mathrm{~mL}$ plastic conical centrifuge tube that contained $25 \mathrm{~mL}$ of ice cold PBS. The samples were kept on ice and transported to the laboratory. The suspension was centrifuged at $250 \times g$ for $15 \mathrm{~min}$ at $4{ }^{\circ} \mathrm{C}$. The cell pellet was suspended in $10 \mathrm{~mL}$ of PBS. Duplicate films were made on glass slides and stained with Wright stain using an automatic slide stainer. Leukocyte differential counts of 200 cells were performed on each slide at a magnification of 1250 using the battlement procedure [21]. Because large lymphocytes in cows may resemble macrophages/monocytes [16], only cells with characteristic amoeboid nucleus and vacuolated moderate blue cytoplasm with or without fine azuorphilic granules were counted as macrophages [21]. On average, $65 \%$ of the cells were macrophages with a viability, as determined by exclusion of Trypan blue, of $98 \%$.

Cross-reactivity of the anti-rbosCD14 $\mathrm{mAb}$ was performed using mouse macrophages, and porcine and equine monocytes. For the preparation of mouse macrophages, primary cultures of mouse fibroblast/macrophages (MEF/Mac) were initiated by explant culture of day-16 to - 18 gestation fetal mice after removal of viscera [14]. Finely minced fetal mouse tissue was plated in T25 flasks in $2 \mathrm{~mL}$ of Dulbecco's modified Eagle's medium with $4.5 \mathrm{~g} / \mathrm{L}$ glucose (high glucose) supplemented with $10 \%$ fetal bovine serum, $2 \mathrm{mM}$ glutamine, and $50 \mathrm{U} / \mathrm{mL}$ penicillin/ streptomycin (10\% DMEM/H). After attachment and initial outgrowth $(\sim 96 \mathrm{~h}), 4 \mathrm{~mL}$ of additional 10\% DMEM/H was added to each primary culture flask. Secondary cultures were produced by washing the primary cultures twice with PBS and once with trypsin-EDTA solution. The released cells were resuspended in 10\% DMEM/H and replated in T25 flasks at a 1:3 split ratio. Secondary MEF/Mac cultures were routinely passaged at a 1:4 split ratio at 7-day intervals until senescence occurred at approximately passage 12 . A culture medium regimen of 3 days on $10 \%$ DMEM/H followed by 4 days on $10 \%$ DMEM/low glucose was maintained over each passage to foster maximum growth of the macrophages. By passage 3-4 approximately $70 \%$ of the cells in the cultures were macrophages.

Monocytes isolated from porcine blood were kindly provided by Dr Joan Lunney (Animal Parasitic Diseases Laboratory, USDA-ARS, Beltsville, MD, USA). Monocytes isolated from equine blood were kindly provided by Dr Martin Furr (Department of Veterinary Medicine, Virginia Tech, Blacksburg, VA, USA). 


\subsection{Immunoblot analysis}

Macrophages isolated from involuted mammary glands were lysed in $2 \%$ lysis buffer as previously described [37]. Nuclei were removed by centrifugation at $31000 \times$ $g$ for $20 \mathrm{~min}$ at $4{ }^{\circ} \mathrm{C}$. The macrophage lysate, milk whey and serum were precleared with $50 \mu \mathrm{L}$ of protein $\mathrm{G}$-Sepharose (Pharmacia, Uppsala, Sweden) for $1 \mathrm{~h}$ at $4{ }^{\circ} \mathrm{C}$ with gentle rocking. The antigens were immunoprecipitated by incubating with anti-rbosCD14 mAb M1-6-6 and M5-2-9-3, or normal mouse serum and with protein G-Sepharose. The immune complexes and proteins that nonspecifically bound to protein G-Sepharose were eluted from protein G-Sepharose by heating at $100{ }^{\circ} \mathrm{C}$ for $3 \mathrm{~min}$ in the loading buffer without 2-mercaptoethanol. The rbosCD14 was resuspended in SDS-PAGE sample buffer, heated and resolved on a 4-12\% Bis-Tris gel (Invitrogen). Separated proteins were electrophoretically transferred to Immobilon-P membrane (Millipore, Bedford, MA, USA) using the Mini-Protean II transfer chamber (Bio-rad). The membrane was blocked overnight at $4{ }^{\circ} \mathrm{C}$ in PBS containing $1 \%$ BSA, washed $2 \times$ with PBS-T and sequentially incubated at room temperature with supernatant of rbosCD14 mAb for $1 \mathrm{~h}$ and goat anti-mouse IgG peroxidase antibody (1:2000 in PBS-1\% BSA) for $30 \mathrm{~min}$. The membrane was washed $5 \times$ with PBS-T, $5 \times$ with distilled water and developed using Sigma Fast DAB peroxidase substrate (Sigma).

\subsection{Flow cytometric analysis}

One-million cells were reacted with antirbosCD14 mAb (1:100), and incubated at $4{ }^{\circ} \mathrm{C}$ for $30 \mathrm{~min}$. The cells were washed $3 \times$ with PBS. Fluorescein isothiocyanate (FITC)labeled affinity-purified antibody to mouse $\operatorname{IgG}+\operatorname{IgM}(\mathrm{H}+\mathrm{L})$ (KPL, Gaithersburg, MD, USA) was added at a 1:100 dilution in PBS to cells reacted with the $\mathrm{mAb}$ and control cells that were not reacted with $\mathrm{mAb}$. After 30 min of incubation at $4{ }^{\circ} \mathrm{C}$, the wells were washed $3 \times$ with PBS and resuspended in
$200 \mu \mathrm{L}$ PBS. Flow cytometric analysis was performed using a Coulter Epics Profile I-Argon laser flow cytometer (Coulter Electronics Inc., Hialeah, FL, USA). The laser was set at $488 \mathrm{~nm}$ wavelength, 7.0 to $7.5 \mathrm{~A}$ current and $15 \mathrm{~mW}$ power; it was aligned by use of fluorospheres (Immuno-Check, Epics alignment fluorospheres, Epics Division, Coulter Corp., Hialeah, FL, USA). Gains for forward-angle light scatter were set at 10, and logarithmic transformations were used for side $\left(90^{\circ}\right)$ light scatter and for green fluorescence. Locations of the cell populations in dot plots had been determined previously on the basis of analyses of pure populations of leukocytes [28]. A bitmap (electronically defined observation area) was drawn around the large mononuclear cell population that contained both large lymphocytes and macrophages, and fibroblasts for the mouse macrophage preparation. Percentage of cells fluorescing $(\% \mathrm{~F})$ and the level of expression of CD14 molecules (log mean fluorescent channel [LMFC]) were recorded by measuring the green fluorescence associated with the gated mononuclear cell population.

\subsection{Use of anti-rbosCD14 to block in vitro release of TNF- $\alpha$ from cultured monocytes}

Blood was collected from the median caudal vein of 5 cows in 15 -mL evacuated tubes containing $1.5 \mathrm{~mL}$ of acid citrate dextrose (40\% trisodium citrate, $14.5 \%$ citric acid, $45.5 \%$ dextrose). For the isolation of monocytes, the blood was centrifuged at $900 \times g$ for 30 min at $4{ }^{\circ} \mathrm{C}$ with the brake disengaged. The buffy coat layer was removed, and transferred into a sterile $40 \mathrm{~mL}$ glass vial containing $20 \mathrm{~mL}$ Hanks' balanced salt solution (HBSS, Invitrogen Corp., Grand Island, NY, USA). Ficoll-paque (Amersham Pharmacia, Biotech, AB, Uppsala, Sweden) (12.5 mL) was layered over the HBSS in a $50 \mathrm{~mL}$ centrifuge tube. After centrifuging for $30 \mathrm{~min}$ at $450 \times g$, the band containing the mononuclear cells was removed and transferred into a $50 \mathrm{~mL}$ centrifuge tube, resuspended in 
$45 \mathrm{~mL}$ of HBSS and centrifuged at $180 \times g$ for $10 \mathrm{~min}$ at $5{ }^{\circ} \mathrm{C}$. Contaminating red blood cells were removed by resuspending the cells in $5 \mathrm{~mL}$ HBSS, $10 \mathrm{~mL}$ of double distilled water was added, gently mixed for $18 \mathrm{~s}$ and then $10 \mathrm{~mL}$ of $2 \times$ minimun essential medium Eagle (Sigma) was added to restore isotensitity. The cell suspension was centrifuged $180 \times g$ for $10 \mathrm{~min}$ at $5^{\circ} \mathrm{C}$ and resuspended in $10 \mathrm{~mL} \mathrm{HBSS}$.

A $1 \mathrm{~mL}$ aliquot of the cell suspension containing $10^{5}$ monocytes was added to 24 well tissue culture plates and incubated for $1 \mathrm{~h}$ at $37^{\circ} \mathrm{C}$. After incubation, the nonadherent cells were removed and then $1 \mathrm{~mL}$ of medium RPMI 1630 (Gibco Brl, Life Technologies, Grand Island, NY, USA) containing penicillin $(100 \mathrm{U} / \mathrm{mL})$, streptomycin $(50 \mu \mathrm{g} / \mathrm{mL})($ Sigma) and 10\% heat-inactivated fetal bovine serum was added. Monocytes were preincubated with $10 \mu \mathrm{g}$ of antirbosCD14 mAb (M1-54-1) or media for $20 \mathrm{~min}$ at $4{ }^{\circ} \mathrm{C}$. Next, LPS $(0.1 \eta \mathrm{g}, 0.01 \eta \mathrm{g}$, $0.001 \eta \mathrm{g}$ ) was added to the wells and incubated for $24 \mathrm{~h}$ at $37^{\circ} \mathrm{C}$ in $5 \% \mathrm{CO}_{2}$. The media from each well was collected and centrifuged at $9300 \times g$ for $30 \mathrm{~min}$. The supernatant was collected and assayed for TNF- $\alpha$ as previously described [29].

\subsection{Statistical methods}

A t-test or analysis of variance with the Tukey post hoc comparison test was used to compare the mean responses between a single experimental group and its control or among multiple experimental groups, respectively. All statistical analyses were performed using GraphPad InStat version 3.05 for Windows (GraphPadSoftware Inc., San Diego, CA, USA). A $P$-value of 0.05 or less was considered significant.

\section{RESULTS}

\subsection{Production of anti-rbosCD14 mAb}

Following immunization with the rbosCD14, 10 murine hybridomas secreting $\mathrm{mAb}$ reactive with the immunogen were identified. Table I summarizes the immunoglobulin isotypes, ELISA and western blot reactive assay results. All antibodies were reactive with rbosCD14, but not with BSA, cell culture media, or with non-immunized mouse serum that were used as negative controls. Representative ELISA results using the strongly reactive mAb M 1-6-6 are illustrated in Figure 1.

\subsection{Intramammary challenge with LPS increases concentration of $\mathrm{SCD} 14$ in milk.}

To determine whether the mAb could be used to detect and quantify sCD14 in whey a sandwich ELISA was used to quantitate sCD14 in milk (Fig. 2). Mammary gland quarters receiving saline alone showed no change in sCD14 levels throughout the study. In contrast, significant $(P<0.05)$ increases in SCD14 were evident within $8 \mathrm{~h}$ of LPS infusion and this increase persisted for an additional $40 \mathrm{~h}$. Maximal levels of sCD14 were observed $24 \mathrm{~h}$ after LPS challenge.

\subsection{Western blotting}

By western blot analysis, all $\mathrm{mAb}$ reacted with a $40 \mathrm{kDa}$ protein for rbosCD14 (Fig. 3). The $\mathrm{mAb}$ also recognized $53 \mathrm{kDa}$ and $58 \mathrm{kDa}$ sCD14 in bovine milk and bovine plasma (Fig. 3). Four additional mAb (M 5-29-3, M 4-2-3, M 3-3-8, M1-6-6) also strongly recognized a $47 \mathrm{kDa} \mathrm{mCD} 14$ protein and a possible accessory $24 \mathrm{kDa}$ protein from a lysate of mammary macrophages (Fig. 4). However, two monoclonal antibodies (M27-2, M 1-54-2) strongly reacted with the $40 \mathrm{kDa}$ recombinant protein but not to the macrophage lysate. Additionally, four monoclonal antibodies (M 1-34-9, M 1-52-8, M 3-9-1) showed only one $47 \mathrm{kDa}$ band from the macrophage lysate (data not shown).

\subsection{The binding of $\mathrm{mAb}$ to macrophages and cross-reactivity studies}

To study binding of anti-rbosCD14 mAb to $\mathrm{mCD} 14$ on macrophages from mammary 

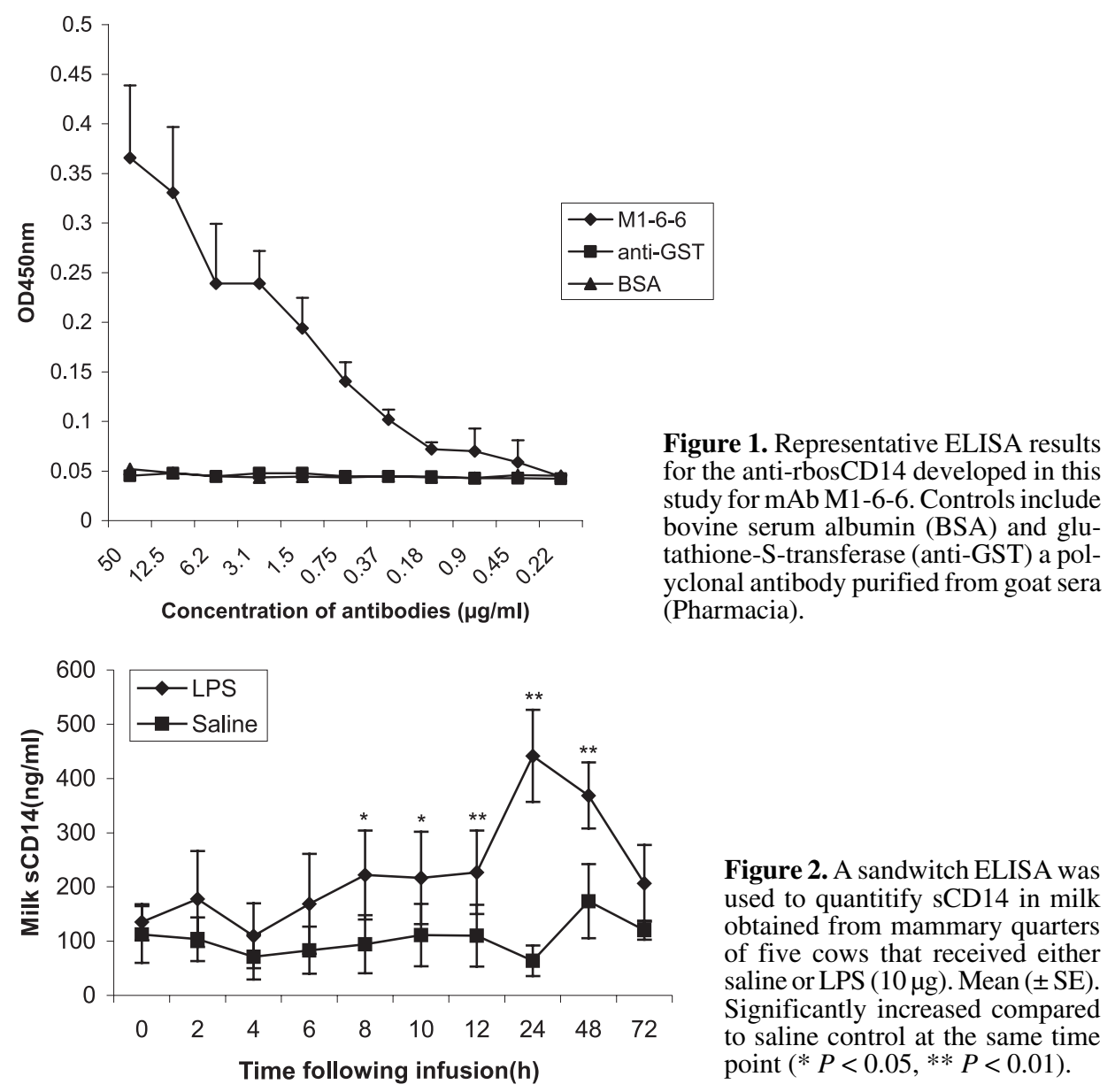

Figure 2. A sandwitch ELISA was used to quantitify sCD14 in milk obtained from mammary quarters of five cows that received either saline or LPS $(10 \mu \mathrm{g})$. Mean $( \pm \mathrm{SE})$. Significantly increased compared to saline control at the same time point $(* P<0.05$, ** $P<0.01)$.

glands of healthy cows and to perform crossreactivity studies, flow cytometry was performed using anti-mouse rbosCD14 mAb. The reactions of the 10 anti-rbosCD14 mAb (diluted 1:1000) with macrophages isolated from involuted bovine mammary glands as measured by flow cytometry is shown (Tab. II). After correcting for autofluorescence of the cell preparation $(9.9 \%)$, the percentage of cells recognized by the $10 \mathrm{mAb}$ ranged from $58.0 \%$ to $66.9 \%$. The log mean fluorescent channel (LMFC) ranged from 3.0 to 4.1. No correction for autofluorescence was applied because with a low percentage of the cells fluorescing, the LMFC will be widely scattered along the $\mathrm{X}$ axis and will cause inflated values for LMFC. MAb M1-6-6 and M3-3-8 showed the highest binding to macrophages from involuted mammary secretions and bound to $67 \%$ (LMFC 16) of cells in a mouse macrophage cell culture. In contrast, these mAb did not bind to blood monocytes isolated from swine and horse blood (data not shown).

\subsection{TNF- $\alpha$ release from monocytes incubated with anti-rbosCD14 mAb and exposed to LPS}

Inhibitory effect of anti-rbosCD14 mAb (M1-54-1) on the LPS induced production 


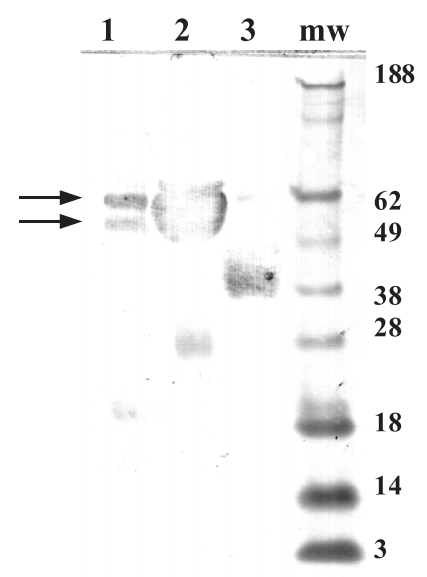

Figure 3. Representative western blot using $\mathrm{mAb}$ M5-29-3 showing identification of 53 and $58 \mathrm{kDa}$ proteins, indicated by arrows, in milk whey (lane 1) in blood plasma (lane 2) and a $40 \mathrm{kDa}$ protein in rbosCD14 (lane 3). Milk whey was prepared eight hours after intramammary injection of $100 \mu \mathrm{g}$ of LPS.

of TNF- $\alpha$ by adherent monocytes during $24 \mathrm{~h}$ of incubation was dose dependent (Fig. 5). The inhibition of TNF- $\alpha$ by antirbosCD14 mAb was obtained at all concentrations of LPS ( 1 to $100 \eta \mathrm{g} / \mathrm{mL}, P<0.05$ ). The greatest inhibition (61\%) of TNF- $\alpha$ production was achieved when $100 \eta \mathrm{g} / \mathrm{mL}$ of LPS was used to stimulate the monocytes. With 1 and $10 \eta \mathrm{g}$ of LPS/mL less inhibition (37\% and 54\%) was observed. The anti-rbosCD14 mAb did not affect the production of TNF- $\alpha$ by unstimulated monocytes (data not shown).

\section{DISCUSSION}

Several of the mouse anti-rbosCD14 mAb developed in this study showed strong reactivity with bovine mammary macrophages by flow cytometry and to sCD14 in milk whey when used in an ELISA. Using the anti-rbosCD14 mAb, we demonstrated that the relative molecular mass for $\mathrm{mCD} 14$ from the bovine macrophage lysate was $47 \mathrm{kDa}$.

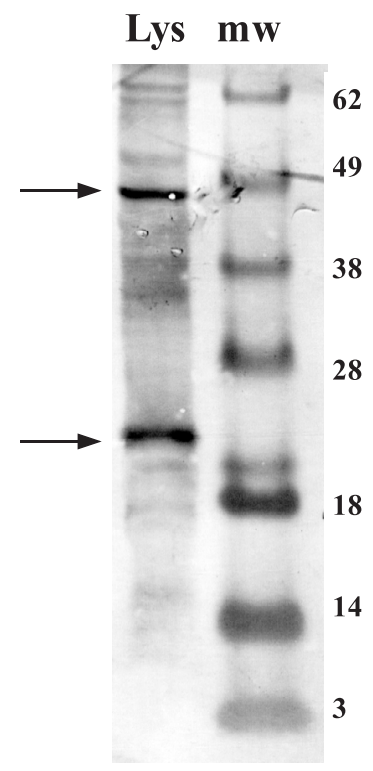

Figure 4. Representative western blot of a macrophage lysate (Lys) using anti-rbosCD14 mAb M1-6-6 showing identification of 47 and $24 \mathrm{kDa}$ proteins (arrows).

Bovine mCD14 is shorter than human mCD14, which has a molecular mass of 50 $58 \mathrm{kDa}$. Also, the ten murine anti-rbosCD14 $\mathrm{mAb}$ developed in this study show different recognition patterns to macrophages by also recognizing a $24 \mathrm{kDa}$ band. This band may be a mCD14 precursor or a truncated mCD14 degradation product. We also demonstrated that SCD14 in bovine milk and blood exists in two forms of 53 and $58 \mathrm{kDa}$. It was previously shown that monocyte and macrophage mCD14 exists in two soluble forms in normal human plasma [8]. These two sCD14, which are referred to as SCD14 $\alpha$ (low Mr) and sCD14 $\beta$ (high Mr), can also be synthesized and released into plasma by normal human monocytes. Different molecular mass forms of sCD14 are present in human serum depending on its origin $[5,8$, 22]. The lower molecular mass forms are derived from the proteolytic cleavage of monocyte mCD14, and, therefore, have a truncated C-terminus without the GPI anchor. These same cells also produce a high molecular mass CD14 receptor lacking the GPI 
anchor, which is directly exocytosed. Varying degrees of glycosylation also contribute to the heterogeneity of the sCD14 molecule [32].

Table II. Reactivity of murine anti-rbosCD14 $\mathrm{mAb}$ with macrophages isolated from involuted bovine mammary glands ( $n=2$ cows $)$ as measured by flow cytometry. Specific mAb binding was detected by FITC-labeled goat-antimouse IgG and IgM.

\begin{tabular}{lcc}
\hline mAb & $\begin{array}{c}\text { Percentage cells } \\
\text { fluorescing }\end{array}$ & $\begin{array}{c}\text { Log mean fluores- } \\
\text { cent channel }^{\text {b,c }}\end{array}$ \\
\hline M1-54-1 & $67.4 \pm 3.8$ & $3.2 \pm 0.7$ \\
M1-34-2 & $68.8 \pm 2.1$ & $3.0 \pm 0.5$ \\
M1-6-6 & $74.9 \pm 8.7$ & $3.7 \pm 0.4$ \\
M3-3-8 & $76.3 \pm 2.5$ & $4.1 \pm 0.5$ \\
M1-34-9 & $68.0 \pm 4.3$ & $3.2 \pm 0.7$ \\
M2-7-7 & $71.8 \pm 4.4$ & $3.4 \pm 0.8$ \\
M1-54-2 & $71.6 \pm 3.1$ & $3.3 \pm 0.6$ \\
M4-2-3 & $73.0 \pm 8.0$ & $3.4 \pm 0.6$ \\
M5-29-3 & $72.1 \pm 6.5$ & $3.5 \pm 0.8$ \\
M5-2-8 $^{\text {Con }}$ & $68.9 \pm 7.9$ & $3.3 \pm 0.8$ \\
Control $^{\text {d }}$ & $9.4 \pm 3.8$ & $1.9 \pm 0.1$ \\
\hline
\end{tabular}

${ }^{a}$ The cell preparation averaged $65 \%$ macrophages.

$\mathrm{b}$ Mean \pm standard error of the mean.

${ }^{c} \mathrm{~A}$ measure of $\mathrm{CD} 14$ receptor density of the cell surface.

${ }^{d}$ Isolated cell preparation incubated with FITClabeled goat anti-mouse IgG and IgM only.
Using the anti-rbosCD14 and ELISA that was developed in this study, we were able to demonstrate an increase in SCD14 in milk whey after intramammary injection of LPS. The increase paralleled previously reported increases in sCD14 in milk whey in response to LPS using commercially available $\mathrm{mAb}$ [3]. In that study, it was also shown that increases in milk neutrophil counts preceded the increase in sCD14. This suggests that neutrophils may be the source of the SCD14, because it was previously shown that neutrophils express SCD14 on their cell surface [28].

Effective approaches for the treatment of Gram-negative infections lag behind the substantive advances made in understanding host mechanisms involved in response to sepsis. This makes the relationship between the timing of delivery and the efficacy of potential therapeutics for septic shock a critical issue. In the present study, LPS induced release of TNF- $\alpha$ by isolated monocytes was reduced by anti-rbosCD14 mAb. The inhibition of TNF- $\alpha$ secretion by anti-rbosCD14 $\mathrm{mAb}$ can be explained by reduced activation of monocytes during interaction of these stimuli with CD14. The inhibitory effect of anti-rbosCD14 mAb on the secretion of TNF- $\alpha$ by LPS stimulated monocytes can be due to impaired binding of these stimuli to CD14 and/or decreased activation of monocytes via CD14. The region of CD14 that

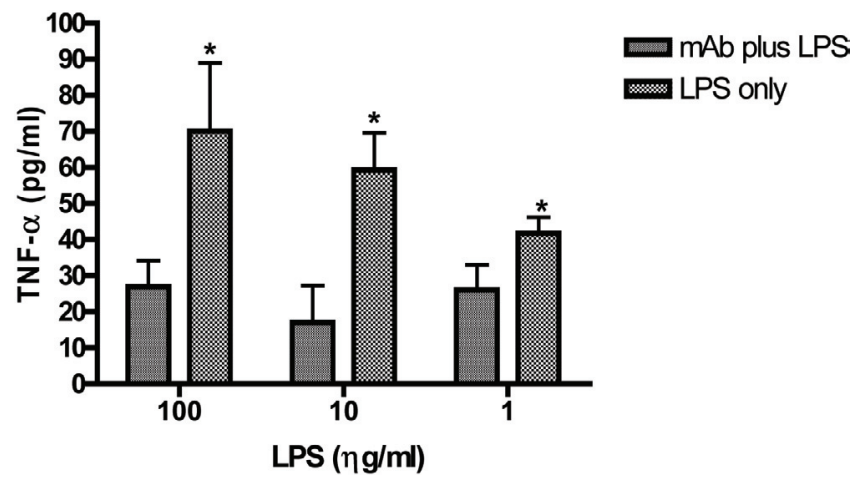

Figure 5. Anti-rbosCD14 mAb inhibits TNF- $\alpha$ response of monocytes after stimulation with LPS. Monocytes were preincubated with anti-rbosCD14 for $1 \mathrm{~h}$ before addition of LPS. Data are presented as the mean \pm standard error of the mean $(n=5$ cows $)$. $* P<0.05$. 
recognizes and binds LPS has been determined $[31,32,36]$, and most likely Gramnegative bacteria bind via LPS at their surface to the same site of CD14. Intact Gramnegative bacteria can bind to $\mathrm{m}$ - and $\mathrm{sCD} 14$ in the presence of serum [33], which indicates that LPS incorporated into the membrane of Gram negative bacteria can interact with CD14. Intact Gram-negative or Grampositive bacteria are more powerful stimuli for cytokine production by monocytes than are shed bacterial components [34]. Thus, it is conceivable that exudates from macrophage containing phagocytosed bacteria include cytokines that are involved in the initial clinical manifestations [34]. It can be anticipated that in vivo, blocking of the CD14 receptor will inhibit the inflammatory response to LPS and may be beneficial in severe sepsis. Indeed, anti-CD14 mAb administered after injection of LPS, protected rabbits from death and renal and pulmonary injury, and prevented hypotension and leukopenia [30]. In cynomolgus monkeys, pretreatment with anti-CD14 mAbs derived from the same murine component $28 \mathrm{C} 5$ as IC 14 prevented LPS induced hypotension and reduced plasma cytokine levels [9]. These results support the concept that anti-CD14 treatment provides a new therapeutic window for the prevention of pathophysiologic changes that result from exposure to LPS during septic shock.

The anti-rbosCD14 mAb developed in the current study may be useful in reducing clinical symptoms associated with augmented release of TNF- $\alpha$ by monocytes. The mAb will afford the opportunity to relate various functional characteristics to specific groups of cells, which will lead to a better understanding of the interrelationship between CD14 and LPS.

\section{REFERENCES}

[1] Antal-Szalmas P., Van Strijp J.A.G., Weersink A.J.L., Verhoef J., Van Kessel K.P.M., Quantitation of surface CD14 on human monocytes and neutrophils, J. Leukoc. Biol. 61 (1997) $721-728$.
[2] Arditi M., Zhou J., Dorio R., Rong G., Goyert S., Kim K., Endotoxin-mediated endothelial cell injury and activation: role of soluble CD14, Infect. Immun. 61 (1993) 3149-3156.

[3] Bannerman D.D., Paape M.J., Hare W.R., Sohn E.J., Increased levels of LPS-binding protein in bovine blood and milk following bacterial lipopolysaccharide challenge, J. Dairy Sci. 86 (2003) 3128-3137.

[4] Bazil V., Horeji V., Baudays M., Kristofova H., Strominger J.I., Kostka W., Hilgert I., Biochemical characterization of a soluble form of the 53-kDa monocytes surface antigen, Eur. J. Immunol. 16 (1986) 1583-1589.

[5] Bufler P., Stiegler G., Shuchmann M., Hess S., Kruger C., Stelter F., Eckerskorn C., Schutt C., Engelmann H., Soluble lipopolysaccharide receptor (CD14) is released via two different mechanisms form human monocytes and CD14 transfectants, Eur. J. Immunol. 25 (1995) 604-610.

[6] Dentener M., Bazil V., Von Asmuth E., Ceska M., Buurman W., Involvement of CD14 in lipopolysaccharide induced tumor necrosis factor-alpha, IL-6 and IL-8 release by human monocytes and alveolar macrophage, J. Immunol. 150 (1993) 2885-2891.

[7] Desidero J.V., Campbell S.G., Bovine mammary gland macrophage: isolation, morphologic features, and cytophilic immunoglobulins, Am. J. Vet. Res. 41 (1980) 1595-1599.

[8] Duriex J.J., Vita N., Popescu O., Guette F., Calzada-Wack J., Munker R., Schmidt R.E., Lupker J., Ferrara P., Ziegler H.W., Labeta M.O., The two soluble forms of the lipopolysaccharide receptor, CD14: Characterization and release by normal human monocytes, Eur. J. Immunol. 24 (1994) 2006-2012.

[9] Didier J.L., Moriarty A.M., Talbott G., Winn R.K., Martin T.R., Ulevitch R.J., Antibodies against CD14 protect primates from endotoxin-induced shock, J. Clin. Invest. 98 (1996) 1533-1538.

[10] Erskine R.J., Tyler J.W., Riddell M.G., Wilson R.C., Theory, use and realities of efficacy and food safety of antimicrobial treatment of acute coliform mastitis, J. Am. Vet. Med. Assoc. 198 (1991) 980-984.

[11] Eberhart R.J., Coliform mastitis, Vet. Clin. North Am. Large Anim. Pract. 6 (1984) 287300 .

[12] Eberhart R.J., Natzke R.P., Newbould F.H.S., Nonnecke B., Thompson P., Coliform mastitis - a review, J. Dairy Sci. 62 (1979) 1-22.

[13] Fetterer R.H., Barfield R.C., Characterization of a developmentally regulated oocyst protein from Eimeria Tenella, J. Parasitol. 89 (2003) 553-564.

[14] Freshney R.I., Culture of animal cells, 3rd ed., Wiley-Liss, New York, 1994, pp. 107-126. 
[15] Frey E.A., Miller D.S., Jahr T.G., Sundan A., Bazil V., Espevik T., Finlay B.B., Wright S.D., Soluble CD14 participates in the response of cells to lipopolysaccharide, J. Exp. Med. 176 (1992) 1665-1671.

[16] Hammer R., Weber A.F., Ultrastructure of agranular leukocytes in peripheral blood of normal cows, Am. J. Vet. Res. 35 (1974) $527-$ 536.

[17] Haziot A., Cehn S., Ferrero E., Low M., Silber R., Goyert S., The monocyte differentiation antigen, CD14, is anchored to the cell membrane by a phosphatidylinositol linkage, J. Immunol. 141 (1988) 547-552.

[18] Haziot A., Tsuberi B.Z., Goyert S.M., Neutrophil CD14: biochemical properties and role in the secretion of tumor necrosis factor-alpha in response to lipopolysaccharide, J. Immunol. 150 (1993) 5556-5565.

[19] Hogan J., Smith K.L., Coliform mastitis, Vet. Res. 34 (2003) 507-519.

[20] Jayaram Y., Hogg N., Expression of CD14 molecules by human neutrophils, Tissue Antigens 33 (1989) 199-204.

[21] Jain N.C., Schalm's veterinary hematology, Lea \& Febiger, Philadelphia, 1986.

[22] Labeta M., Durieux J.J., Fernandes N., Herrmannn R., Ferrara P., Release from a human monocyte-like cell line of two different soluble forms of the lipopolysaccharide receptor, CD14, Eur. J. Immunol. 23 (1993) 2144-2151.

[23] Lee J.-W., Paape M.J., Elsasser T.H., Zhao X., Elevated milk soluble CD14 in bovine mammary glands challenged with Escherichia coli lipopolysaccharide, J. Dairy Sci. 86 (2003) 2382-2389.

[24] Lee J.-W., Paape M.J., Elsasser T.H., Zhao X., Recombinant soluble CD14 reduces severity of intramammary infection by Escherichia coli, Infect. Immun. 71 (2003) 4034-4039.

[25] Lee J.-W., Paape M.J., Zhao X., Recombinant bovine soluble CD14 reduces severity of experimental Escherichia coli masititis in mice, Vet. Res. 34 (2003) 307-316.

[26] Maliszewski C., Ball E., Graziano R., Fanger M., Isolation and characterization of My 23, a myeloid cell-derived antigen reactive with the monoclonal antibody AML-2-23, J. Immunol. 135 (1985) 1926-1936.

[27] National Mastitis Council, Current concepts of bovine mastitis, 4th ed., National Mastitis Council, Madison, 1996.

[28] Paape M., Lilius E.,Wiitanen P., Kontio M., Miller R.H., Intramammary defense against infectious induced by Escherichia coli in cows, Am. J. Vet. Res. 57 (1996) 477-482.

[29] Paape M.J., Rautiainen P.M., Lilius E.M., Malstrom C.E., Elsasser T.H., Development of anti-bovine TNF- $\alpha \mathrm{mAb}$ and ELISA for quantitating TNF- $\alpha$ in milk after intramammary injection of endotoxin, J. Dairy Sci. 85 (2002) 765-773.

[30] Schimke J., Mathison J., Morgiewicz J., Ulevitch R., Anti-CD $14 \mathrm{mAb}$ treatment provides therapeutic benefit after in vivo exposure to endotoxin, Proc. Natl. Acad. Sci. USA 95 (1998) 13875-13380.

[31] Shapiro R.A., Cunningham M.D., Ratcliffe K., Seachord C., Blake J., Bajorath A., Aruffo A. Dadveau P., Identification of CD14 residues involved in specific lipopolysaccharide recognition, Infect. Immun. 243 (1997) 100-109.

[32] Stelter F., Pfister M., Bernheiden M., Jack R.S., Bufler P., Engelmann H., Schutt C., The myeloid differentiation antigen CD14 in Nand $\mathrm{O}$-glycosylated: contribution of $\mathrm{N}$-linked glycosylation to different soluble CD14 isoforms, Eur. J. Biochem. 236 (1996) 457-464.

[33] Stelter F., Bernheiden M., Menzel R., Jack R.S., Witt S., Fan X., Phister M., Schutt C., Mutation of amino acids 39-44 of human CD14 abrogates binding of lipopolysaccharide and Escherichia coli, Eur. J. Biochem. 243 (1997) 100-109.

[34] Van Furth A.M., Verhard-Seijmonsbergen E.M., Langermans J.A.M., Van Dissel J.T., Van Furth R., Anti-CD14 monoclonal antibodies inhibit the production of tumor necrosis factor alpha and interleukin-10 by human monocytes stimulated with killed and live Haemophilus influenzae or Streptococcus pneumoniae organisms, Infect. Immun. 67 (1999) 3714-3718.

[35] Verbon A., Dekkers P.E., Van Hove T., Hack C.E., Pribble J.P., Turner T., Souza S., Axtelle T., Hoek F.J., Van Deventer S.J., Van der Poll T., CD14 and anti-CD14 antibody, inhibits endotoxin-mediated symptoms and inflammatory responses in humans, J. Immunol. 166 (2001) 3599-3605.

[36] Viriyakosol S., Kirkland T.N., The N-terminal half of membrane CD14 is a functional cellular lipopolysaccharide receptor, Infect. Immun. 64 (1996) 653-656.

[37] Wang Y., Paape M.J., Leino L., Capuco A.V., Narva H., Functional and phenotypic characterization of monoclonal antibodies to bovine L-selectin, Am. J. Vet. Res. 58 (1997) 1392 1401.

[38] Wang Y., Zarlenga D.S., Paape M.J., Dahl G.E., Recombinant bovine soluble CD14 sensitizes the mammary gland to lipopolysaccharide, Vet. Immunol. Immunopathol. 86 (2002) $115-124$

[39] Wright S.D., Ramos R.A., Tobias P.S., Ulevitch R.F., Mathisioon J.C., CD14, a receptor for complexes of lipopolysaccharide (LPS) and LPS binding protein, Science 249 (1990) 1431-1433. 